\title{
Factors in the Soviet Decision to Invade Czechoslovakia
}

\author{
Antony Kalashnikov
}

This essay describes the factors in the Soviet decision to invade Czechoslovakia and argues that the principle motive was to prevent political reforms which would have established Czechoslovakia as multi-party state. The paper will be organized in three parts: after establishing factual background of the 'Prague Spring' reforms, the essay outlines the various factors contributing to the decision. I will then analyze them in comparative historical light in order to single out the most important reason for the invasion.

\section{Introduction}

On the night of August 20-21, 1968, Warsaw Pact troops led by the Soviet Union crossed the Czechoslovakian borders and occupied the country in an impeccably executed manoeuvre lasting only a few hours. General Secretary Alexander Dubcek and other key figures of the Communist Party of Czechoslovakia were immediately seized and brought to Moscow before the Politburo. There, they signed the Moscow Protocols, repealing all the reforms launched in the preceding months, dubbed the 'Prague Spring'. Dubcek remained nominally in his post, but was voted out within a few months and replaced with the conservative leader Gustav Husak. These events epitomized the Brezhnev Doctrine, whereby the Soviet Union showed its commitment to hold on to its interests in Eastern Europe even if it meant resorting to military action.

This essay will describe the factors in the Soviet decision to invade Czechoslovakia and argue that the principle motive was to prevent political reforms which would have established Czechoslovakia as a multi-party state. The paper will be organized in three parts: after establishing factual background to the 'Prague Spring' reforms, the essay outlines the various factors which contributed to the decision. I will then analyze them in a comparative historical light in order to single out the most important reason for the invasion.

\section{Background}

In several respects, Czechoslovakia in the late 1960s had reached an impasse of sorts in both the economic and political spheres. The five-year economic plan of 1960, which experimented with a half-hearted partial decentralization of enterprise, led to such a severe turndown that it had to be cancelled in 1963. ${ }^{1}$ The neither-here-nor-there approach spawned inflation, and attempts to solve the situation in the following years fell through. By 1967, it became evident that massive economic reform was necessary; thus, the $13^{\text {th }}$ Party Congress instituted a series of decentralization reforms, which were, once again, insufficient and largely unsuccessful. ${ }^{2}$

In the political arena, Czechoslovak governance continued to be characterized by an authoritarian, heavy-handed handling of society by the communist party. For one thing, the pace of deStalinization was sluggish, as the political elite itself was complicit in the crimes. ${ }^{3}$ This dynamic must be viewed as part of the backdrop of democratic tradition in Czechoslovakia- the people were

1 Robert Rhodes James, The Czechoslovak Crisis 1968 (London: Weidenfeld and Nicolson, 1969), 3.

2 Ibid, 6-7.

3 Kieran Williams, The Prague Spring and its Aftermath: Czechoslovak Politics, 1968-1970 (Cambridge: Cambridge University Press, 1997), 7. 
much more sensitive to strict control and authoritarian measures. ${ }^{4}$ Ethnic tensions between Czechs and Slovaks began to simmer; the latter demands for autonomy were consistently and insensitively denied by the government. ${ }^{5}$ By the late 1960s, the government reacted to growing discontent by imposing stricter political control. ${ }^{6}$ However, this policy backfired very quickly, as popular support declined to dangerous levels. ${ }^{7}$

With the election of Alexander Dubcek as the communist party's First Secretary on January 5, 1968, the new leadership pushed through a series of sweeping reforms to deal with these problems. Economic developments were expanded to significantly restructure the Czechoslovakian economy, introducing the goal of a convertible Czechoslovak currency, policies for opening the economy to the world market, and partial market reforms were passed. Immediately afterwards there came a purge of orthodox party members at the start of the year, and the subsequent liberalization of the press and radio. ${ }^{8}$ Following these reforms came the so-called 'Action Program' of April 9. It included a Press Law prohibiting censorship, mobility rights, freedom of conscience safeguards, rehabilitation of political victims, a constitutional restructuring of a federation with Slovakia and importantly, the recognized need for minority parties in parliament. ${ }^{9}$

For a number of reasons, these changes were unacceptable to the Soviet Union. The initial response of the Soviet Union was to put pressure on Czechoslovakia to abandon its reformist course. This pressure took the form of diplomatic negotiations including Dresden in mid-March, a propaganda campaign, and intimidation through Warsaw Pact military exercises inside Czechoslovakia. ${ }^{10}$ In July 1968, talks were held in Cierna-nad-Tisou, in which the Soviet side tried to reach a compromise with Dubcek - Czechoslovakia would remain in the Warsaw Pact and Comecon, it would not permit the establishment of a multi-party system, and it would increase censorship of the press. ${ }^{11}$ The USSR, in turn, would not interfere with the internal affairs of the Czechoslovak government. ${ }^{12}$ These talks were formalized in the Bratislava Declaration on August 3, which was co-signed by the Warsaw 5 USSR, Poland, East Germany, Hungary, and Bulgaria. ${ }^{13}$ However, on August 10, the Czechoslovak Communist Party published their Draft Party Statutes for the $14^{\text {th }}$ Party Congress. These Statutes were the logical progression of the Action Plan, and included important points on the right to dissent, limitation on tenure of Party posts, and secret ballots. ${ }^{14}$ The Czechoslovakians had either gone back on their promises at Bratislava, or lost control of the situation. It was in this context that the Soviet decision to invade was made (presumably on August 13, according to historian Robert James) and successfully carried out in the matter of a week. ${ }^{15}$

\section{Factors for Invasion}

\footnotetext{
4 Ibid, 11.

5 James, The Crechoslovak Crisis 1968, 4-5.

6 Philip Windsor and Adam Roberts, Czechoslovakia 1968: Reform, Repression and Resistance (New York: Columbia University Press, 1969), 7.

7 James, The Caechoslovak Crisis 1968, 7.

8 Windsor and Roberts, Czechoslovakia 1968, 18.

9 James, The Czechoslovak Crisis 1968, 19.

10 Karen Dawisha, The Kremlin and the Prague Spring (Berkeley: University of California Press, 1984), 37-46.

11 Jiri Valenta, Soviet Intervention in Czechoslovakia, 1968: Anatomy of a Decision (Baltimore: Johns Hopkins University Press, 1979), 82-83.

12 Ibid.

13 Ibid, 85.

14 James, The Czechoslovak Crisis 1968, 28.

15 Ibid, 29.
} 
Several factors compounded to provide the impetus for the Soviet invasion of Czechoslovakia. Viewed against the backdrop of the 'time factor', these factors included the economic, geostrategic, ideological, and political. Economically, the USSR was fearful of Czechoslovakia losing its dependence on the Soviet Union and finding other, Western trade partners. For example, Western governments had indicated their interest in financing some of Dubcek's economic reforms. ${ }^{16}$

In many ways the Soviet Union saw Czechoslovakia as being in a crucial geo-strategic position in Europe. Even though Dubcek constantly affirmed his commitment to remain in the Warsaw Pact, the Soviet Union could see how unpredictable Czechoslovakian foreign policy could become. The geo-strategic implications of losing the country were, however, very severe. For one thing, the Czechoslovak army held an important defensive area in Central Europe, further west than any other Soviet satellites. ${ }^{17}$ Vital war industries supplying the Warsaw Pact military were also based out of the country. More importantly, Czechoslovakia leaving the Warsaw Pact would also result in a powervacuum in central Europe. The Soviet leadership was particularly fearful of West Germany reasserting its rising economic and political strength (which was dubbed 'German revanchism' in Soviet propaganda) and potentially expanding into a neutral Czechoslovakia. ${ }^{18}$ Also contributing to Soviet fears of Czechoslovak foreign policy drift were high-level meetings held in August with Josip Tito and partially-deviant Nicolae Ceausescu. ${ }^{19}$

Dubcek's plan to build a "socialism with a human face" in Czechoslovakia also caused worry to the Soviet leadership, as it represented an ideological challenge to the bureaucratic socialist status quo. For one thing, Dubcek's reforms implied that Soviet-style socialism lacked "a human face" and required a re-examination. Furthermore, the 'Prague Spring' affirmed nationalism, which flew in the face of complex federations such as the USSR. ${ }^{20}$ These ideas could potentially spread to the rest of the Eastern Bloc and the Soviet Union itself. Already students in Poland and Soviet intellectuals expressed interest and even sympathy with Czechoslovakian reforms-these feelings advanced further with time. ${ }^{21}$

The changing political structure of Czechoslovakia was also an important factor in the decision to invade. The shake-up of cadres in the party was unacceptable to the Soviet Union, as its most trusted partners were being replaced by leaders unfavourable to Soviet Union's policies. ${ }^{22}$ Much more important to the Soviet decision, however, was the fear of an essentially one-party system (Czechoslovakia did have a few puppet minor parties which played no role in government) breaking down. Indeed, Dubcek's reforms freed the press to debate the role and structure of the Party itself. Furthermore, alternative citizens' groups were forming up, such as 'Committed Non-Party Persons' association and clubs for former political prisoners. ${ }^{23}$ Not only did this destabilize socialism in Czechoslovakia, but it also affected the "unity and cohesion of the socialist bloc" which was disrupted by the departure of reticent states. ${ }^{24}$

16 Roger E. Kanet, "Czechoslovakia and the Future of Soviet Foreign Policy," in The Soviet Invasion of Czechoslovakia: Its Effects on Eastern Europe, ed. E. J. Czerwinski and Jaroslaw Piekalkiewicz (New York: Praeger Publishers, 1972 ), 93.

17 James, The Czechoslovak Crisis 1968, 16.

18 Kanet, "Czechoslovakia and the Future of Soviet Foreign Policy," 93.

19 James, The Czechoslovak Crisis 1968, 29.

20 Valenta, Soviet Intervention in Czechoslovakia, 15.

21 Kanet, "Czechoslovakia and the Future of Soviet Foreign Policy," 93.

22 James, The Crechoslovak Crisis 1968, 18.

23 Ibid, 22.

24 Mark Krammer, "The Prague Spring and the Soviet Invasion in Historical Perspective," in The Prague Spring and the Warsaw Pact Invasion of Czechoslovakia in 1968, ed. Gunter Bischof et al. (Plymouth: Lexington Books, 2010), 44. 
All of the above reasons for invasion must be qualified by the 'time factor' interpretation advanced by historian Karen Dawisha. Basically, she argues that invasion was not the only solution to the Czechoslovak crisis - other ways of dealing with it were on the table. Moreover, the Soviet leadership lacked a decisive will to go through with the invasion, preferring a diplomatic, political solution. It was only the so-called 'time factor' which tipped the scales, as an invasion was the only 'quick' means possible to diffuse the situation. ${ }^{25}$ Had the $14^{\text {th }}$ Party Congress been held on September 9 (or even the Slovak congress on August 26), there would be no way of rolling back the reforms. ${ }^{26}$ Not only would they have gained permanent legitimacy, but conservative party members would have lost their posts and the Soviet Union would lose its leeway over internal Czechoslovak politics. In such a way, even if the reforms did not pose a deadly threat to Soviet interests, the Congress was a step into the unknown which, on first glance, promised instability. ${ }^{27}$ This time necessity forced the cards of the Soviets, and resulted in an invasion.

\section{Analysis}

An effective way to assess the most important factors in the Soviet invasion of Czechoslovakia would be to interrogate the factors in a comparative historical context of Soviet foreign relations. Thus, one may look at the elements in the domestic and foreign politics of Eastern Bloc countries which resembled Dubcek's Czechoslovak but did not prompt a Soviet invasion. Thus, for instance, in terms of the economic factor - Hungary had launched its 'New Economic Mechanism' in 1968, which was very similar to the Czechoslovakian policies. In a massive, de-centralizing sweep, the Hungarian government devolved medium-scale investment to enterprises, introduced market control of goods, began the integration into the world-economy, and made central industrial planning non-binding. ${ }^{28}$ Some critics even go so far as to interpret the 'New Economic Mechanism' as "a de facto renunciation of central planning, limited only by the political constraints [of being] allied to the Soviet Union." 29 Either way, the Soviet Union did not intervene in Hungary and allowed its liberalized economy to co-exist in a far more rigid communist bloc.

A parallel in terms of the geostrategic/ foreign factor could also be found in Romania. Though Romania remained in the communist camp, it persisted in exercising a very independent line in military and foreign affairs. It refused to take part in the Warsaw Pact manoeuvres, passed restrictive laws on the movement of foreign troops through its territory, built up autonomous militia units while decreasing the size of its army, failed to convert its railways to Eastern Bloc gauge, and kept up military contacts with China and Yugoslavia. ${ }^{30}$ Likewise, in terms of foreign policy, it deviated much more than Czechoslovakia ever even had an opportunity to do. Among other things, Romania reopened territorial disputes with USSR over Bessarabia, unilaterally recognized West Germany, and never broke off ties with Israel after $1967 .^{31}$ Even though Romanian military intelligence later made the claim that the Soviet Union was on the brink of occupying the country along with Czechoslovakia, little historical evidence exists to support it. At any rate, the USSR allowed Romania to pursue a much larger, though limited, autonomy than Dubcek's Czechoslovakia ever sought.

25 Dawisha, The Kremlin and the Prague Spring, 309-310.

26 Ibid, 310.

27 Valenta, Soviet Intervention in Czechoslovakia, 157.

28 David Granick, “The Hungarian Economic Reform,” World Politics 25 (April 1973): 415-416.

29 Ibid, 414.

30 Aurel Braun, Romanian Foreign Policy since 1965: The Political and Military Limits of Autonomy (New York: Praeger Publishers, 1978), 88.

31 Dennis Deletant, “Taunting the Bear': Romania and the Warsaw Pact, 1963-89," Cold War History 7 (November 2007): 497, 499. 
There were also similarities between the ideological stirrings of the Prague Spring and those a decade later in Poland. Indeed, striking workers phrased their demands for a comprehensive re-orientation of Poland's society in terms very similar to Dubcek's plea for "socialism with a human face." Calling for an abolition of "the red bourgeoisie," many saw their actions as class struggle for a rejuvenated socialism free of bureaucracy and corruption. ${ }^{32}$ Although the Soviet Union put pressure on Poland to resolve its problems and probably played a part in the latter's instituting martial law, direct military intervention was never contemplated. ${ }^{33}$

This leaves the political issue as the most important in the Soviet decision to invade Czechoslovakia. In my understanding, it was crucial because all other factors depended upon it. Indeed, Soviet influence in Eastern Europe was predicated upon the co-operation of the communist governments in power. The amount of resources needed for direct control of an unwilling population would have far outstripped any benefits. This is the reason the Soviet Union was forced to allow its satellites vacillations in both domestic and foreign policies. The point that could not be compromised on, however, was the endurance of the local regimes to guarantee the pro-Soviet course. Given the lack of real democratic legitimacy of communist governments, they could only function on the basis of a one-party state. The late 1980s demonstrated not a single state remained communist after implementing a multi-party system. If Czechoslovakia was to implement democratic rule, there would be little room for the compromises shown in the cases above. Consequently, if Czechoslovak leaders were too fatuous to realize that their policies were leading to the regime's self-destruction, the Soviet intervention reminded them and the rest of the Eastern Bloc of the political realities of running a viable communist state.

\section{Conclusion}

In such a way, this essay has elucidated the various factors which contributed to the Soviet decision to invade Czechoslovakia. By situating the invasion in a comparative, historical context, I have argued that the political aspect was the most important, bringing together all the other factors. If Czechoslovakia no longer was a single-party state, it would very quickly succumb to popular pressures and shed all of its vestiges of Communism. This would entail the complete loss of everything Czechoslovakia meant to the Soviet Bloc compounded with the destabilizing effects of a precedent set by Soviet officials for other countries, and, indeed, for the Soviet Union itself.

32 Jacek Tittenbrun, The Collapse of 'Real Socialism' in Poland (London: Janus Publishing Company, 1993), 56-57. 33 Ibid, 106-107. 


\section{Bibliography}

Braun, Aurel. Romanian Foreign Policy since 1965: The Political and Military Limits of Autonomy. New York: Praeger Publishers, 1978.

Dawisha, Karen. The Kremlin and the Prague Spring. Berkeley: University of California Press, 1984.

Deletant, Dennis. “Taunting the Bear': Romania and the Warsaw Pact, 1963-89." Cold War History 7 (November 2007): 495-507.

Granick, David. “The Hungarian Economic Reform.” World Politics 25 (April 1973): 414-429.

Kanet, Roger E. "Czechoslovakia and the Future of Soviet Foreign Policy." In The Soviet Invasion of Czechoslovakia: Its Effects on Eastern Europe. Edited by E. J. Czerwinski and Jaroslaw Piekalkiewicz, 91103. New York: Praeger Publishers, 1972.

Krammer, Mark. "The Prague Spring and the Soviet Invasion in Historical Perspective." In The Prague Spring and the Warsaw Pact Invasion of Czechoslovakia in 1968. Edited by Gunter Bischof et al., 35-61. Plymouth: Lexington Books, 2010.

James, Robert Rhodes. The Czechoslovak Crisis 1968. London: Weidenfeld and Nicolson, 1969.

Tittenbrun, Jacek. The Collapse of Real Socialism' in Poland. London: Janus Publishing Company, 1993.

Valenta, Jiri. Soviet Intervention in Czechoslovakia, 1968: Anatomy of a Decision. Baltimore: Johns Hopkins University Press, 1979.

Williams, Kieran. The Prague Spring and its Aftermath: Cžechoslovak Politics, 1968-1970. Cambridge: Cambridge University Press, 1997.

Windsor, Philip and Adam Roberts. Cžechoslovakia 1968: Reform, Repression and Resistance. New York: Columbia University Press, 1969. 